\title{
A new lithostratigraphic framework for the Anti-Atlas Orogen, Morocco
}

\author{
R. J. THOMAS ${ }^{1}$, A. FEKKAK ${ }^{2}$, N. ENNIH ${ }^{2}$, E. ERRAMI ${ }^{2}$, E. S. LOUGHLIN ${ }^{3}$, P.G. GRESSE ${ }^{4}$, L.P. \\ CHEVALLIER $^{4}$ and J-P. LIEGEOIS ${ }^{5}$ \\ ${ }^{1}$ British Geological Survey, Kingsley Dunham Centre, Keyworth, NG12 5GG, Notts, UK \\ ${ }^{2}$ Université Chouaib Doukkali, El Jadida, Morocco \\ ${ }^{3}$ British Geological Survey, Edinburgh, UK \\ ${ }^{4}$ Council for Geoscience, P.O. Box 572, Bellville, 7535, South Africa \\ ${ }^{5}$ Africa Museum, B-3080 Tervuren, Belgium
}

ABSTRACT - A new lithostratigraphic nomenclatural framework is proposed for the Anti-Atlas Orogen of Morocco, to replace the previous chronostratigraphic scheme. All the lithostratigraphic units of the Anti-Atlas Orogen are well represented in the Sirwa, Kerdous and Sarhro inliers and examples from these areas are given prominence, though correlates in other areas are given, where known. The oldest, Palaeoproterozoic, rocks of the cratonic basement form the northern part of the West African Craton and can be subdivided into a series of Complexes (made up of constituent Groups, Suites etc), depending on geographical outcrop (e.g. the Zenaga and Kerdous Complexes in the Sirwa and Kerdous inliers respectively). The Neoproterozoic rocks deposited on this basement are termed the Anti-Atlas Supergroup, within which five groups of volcano-sedimentary units (Taghdout, Jbel Lkst, Sarhro, Iriri, and Bou Azzer Groups) and various intrusive igneous rocks are recognised (e.g. Ifzwane and Toudma Suites). These units are related to the earliest passive margin, oceanic and island-arc development phases of the orogen between $\sim 800$ and $660 \mathrm{Ma}$. The earliest Pan-African deformation (at $\sim 660 \mathrm{Ma}$ ) resulted from closure of the ocean basin, SW-directed thrusting and accretion of the island-arc remnants. Continued prolonged convergence gave rise to a sinistral transpressional regime in which late syn- to post-tectonic continental volcanic and clastic sequences of the Ouarzazate Supergroup were deposited. The first rocks of this new tectonic regime were deposited in narrow, tectonically active, strike-slip pull-apart rift basins (Bou Salda, Mgouna, Tafrawt and Anzi Groups), associated with intrusion of high-K calc-alkaline granitoid batholiths (e.g. Assarag, Bardouz Suites) and the juxtaposition of ophiolitic remnants in major strike-slip shear belts. These were followed by the deposition of the much more areally extensive continental volcano-sedimentary molasse, the volcanic components of which were erupted from several interfingering volcanic centres, often associated with caldera complexes and sub-volcanic alkaline granites 
(Toufhgrane, Tanghourt and Guellaba Suites). The proposed lithostratigraphic scheme encompasses all the major rock units identified in the literature from the orogen and is flexible so that new, lower-ranking, units can be placed at the appropriate stratigraphic level in future. This framework is supported by new high-precision U-Pb zircon dates that have recently become available.

\section{INTRODUCTION}

The Anti-Atlas Orogen of Southern Morocco is amongst the most important segments of the major Pan-African $(\sim 0.5 \mathrm{Ga})$ belt system of North Africa. The orogen is exposed in a series of near-continuous, SW-NE trending outcrops that stretch over $700 \mathrm{~km}$ across southern Morocco (Fig. 1). The belt is over $150 \mathrm{~km}$ wide in the central part, west of Ouarzazate. Scattered outcrops of related rocks in NW Algeria show that from SE Morocco, the belt continues southeastwards with a NW-SE trend. The Anti-Atlas orogen comprises two main sequences of rocks - a metamorphic basement of Palaeoproterozoic $(\sim 2 \mathrm{Ga})$ age and the Neoproterozoic rocks of the orogen proper. The Palaeoproterozoic rocks form the northern margin of the West African Craton mainly outcropping in the Reguibat Shield in Mauritania and Algeria. The Palaeoproterozoic basement is exposed in a series of uplifted inliers ("boutonnières"), surrounded by the Neoproterozoic rocks that were locally deformed with the basement during the Pan African Orogeny.

Over the past decade, there has been a considerable volume of research on the Anti-Atlas Orogen, and a number of broadly comparable models for the evolution of the belt have been proposed (e.g. Hefferan et al., 1992, Saquaque et al., 1992, Ennih and Liégeois, 2001, Thomas et al., 2002, Walsh et al., 2002). Most of these have concentrated on sedimentological-volcanological, structural, geochemical and, more recently, geochronological studies. However, apart from the study of the Sirwa Inlier by Thomas et al. (2002), few regional mapping and synthetic stratigraphic studies have been published. More importantly, there is no broadly accepted lithostratigraphic framework for the Anti-Atlas orogen as a whole.

In March 2002, the $19^{\text {th }}$ Colloquium of African Geology was held in El Jadida, Morocco and large number of papers on Anti-Atlas geology were presented. Following the meeting a field excursion was held in the Sirwa-Sarhro region of the central/eastern Anti-Atlas and a number of regional correlations became very clear. In this paper, we review what is currently known about the geological evolution of the central and eastern part of the Anti-Atlas Orogen and construct a new lithostratigraphic framework for all the various rock sequences involved. One of the main 
purposes of the paper is to erect the framework in such a way so that, in future, newly identified units can be formally named and slotted into the appropriate stratigraphic position.

\section{EXISTING CHRONOSTRATIGRAPHIC SYSTEM VERSUS A LITHOSTRATIGRAPHIC APPROACH}

Up until the late 1990's the Precambrian of Morocco was traditionally subdivided according to chronostratigraphic principles. This involves a basic subdivision into 3 "Systems" with PI = Archaean or Palaeoproterozoic; PII = Lower and Middle Neoproterozoic and PIII = Upper Neoproterozoic (e.g. Choubert, 1963). Each "P"-stage was then further subdivided into various "Series" (e.g. PIII ${ }^{1}, \mathrm{PIII}^{2}, \mathrm{PIII}$, oldest to youngest). Of course this system assumes that the age of the rocks is known, and that has not been the case in the Anti-Atlas (until recently) with a marked dearth of reliable isotopic age-data. If the ages were not known, the higher the metamorphic grade the rocks, the older they were assumed to be. This simplistic picture is now known to be usually misleading and often downright erroneous. The resulting legends on geological maps were very confusing, with a multiplicity of terms such as "complexes", "series", "chains" and "massifs". Often these terms were restricted to very small geographically defined rock masses, such that the regional stratigraphic relations were difficult to understand.

Presently, an international body, the IUGS (International Union of Geological Sciences) and its organs for stratigraphy, the ICS (International Commission on Stratigraphy) and the ISSC (International Subcommittee on Stratigraphic Classification) recommends a lithostratigraphic approach, in which rock masses are classified and correlated on their lithological characteristics and grouped together accordingly (Supergroups down to Groups, Subgroups, Formations and Members etc for layered sedimentary and volcanic sequences and Suites, Complexes etc for plutonic igneous and some metamorphic rocks). The lithostratigraphic approach adopted here for the Anti-Atlas Orogen, follows the first attempt at such an approach in the region. This project was initiated by the Council for Geoscience of South Africa for a $7 \times 1$ : 50000 geological mapping area in the Sirwa Inlier (Thomas et al., 2002) and the British Geological Survey in the Kerdous, Bas Draa and Sarhro regions. In collaboration with other research groups in Morocco and elsewhere, we attempt here to broaden this system to cover the entire eastern Anti-Atlas. Hopefully, in future, this stratigraphic framework can be applied throughout the Anti-Atlas orogen and possibly to adjacent Pan-African belts. In the following system, all names that we propose should be adopted as formal lithostratigraphic terms are shown in bold type when first used. In most cases, we have only mentioned formalised names at the group level, though certain critical formations are also quoted. 


\section{PALAEOPROTEROZOIC BASEMENT (2200 to $2030 \mathrm{Ma)}$}

The medium-grade metamorphic and plutonic rocks upon which the Neoproterozoic rocks in the Anti-Atlas were deposited are now well established as Palaeoproterozoic in age within a range of 2200 to $2030 \mathrm{Ma}$ (Aït Malek et al., 1998; Thomas et al., 2002). They thus represent products of the Eburnian-Birimian orogenic event recognised in many parts of the West African Craton. In Morocco, the rocks outcrop in a number of isolated "boutonnières", of which the largest, the Zenaga inlier (part of the larger Sirwa inlier) represents part of an Eburnian orogen (Fig. 2). The Zenaga inlier, like all the other Palaeoproterozoic inliers in the Anti-Atlas belt, is characterised by similar older sequences of layered supracrustal schists, paragneisses and migmatites, interpreted as polycyclic metamorphosed volcano-sedimentary rocks, intruded by various plutonic rocks which are predominantly granitic to granodioritic in composition.

In perhaps the best-known example of a basement inlier, the outcrop at Zenaga, the Palaeoproterozoic rocks are termed the Zenaga Complex (Figs. 2 and 3). The complex consists of supracrustal schists, gneisses and migmatites known as the Zenaga Group. The Zenaga Group is possibly dated at $\sim 2170 \mathrm{Ma}$, based on the U-Pb zircon SHRIMP dates obtained from relict zircon cores from intruding granites (Thomas et al., 2002). In future, subdivision of the Zenaga Group into formations may be possible. The schists are intruded by a number of calc-alkaline plutonic rocks, three of which have been dated by Thomas et al., (2002) - the Assourg Tonalite (2037 $\pm 7 \mathrm{Ma}$ ) the Azguemerzi Granodiorite (2032 $\pm 5 \mathrm{Ma})$ and the Tazenakht Granite (2037 $\pm 9 \mathrm{Ma}=$ Tamazzarra Granite of Thomas et al., 2002). It is proposed that these rocks be collectively grouped into the Tazenakht Suite.

Similarly, in the Kerdous inlier, the Kerdous Complex comprises Palaeoproterozoic rocks comparable to those of the Zenaga Complex, though of lower metamorphic grade (Figs. 2 and 3). The oldest supracrustal rocks, equivalent to the Zenaga Group, are schists, phyllites and psammites of probable turbiditic origin, known as the Had-n-Tahala Group (BGS, 2001a, b). Several calc-alkaline granites that have been dated by the U-Pb zircon PIMMS method intruded these rocks. They fall in a similar age range to those of the Tazenakht Suite and include the Amaghouz Granite (2042 $\pm 1 \mathrm{Ma}$ ), the Anammr Granite (2058 $\pm 11 \mathrm{Ma})$ and the Tahala Granite (2060 \pm 12 Ma; BGS, 2001a). Some granites which intrude the Had-n-Tahala Group gave older dates, but with poor precision, such as the Agrsiyf Granite which gave $2263 \pm 38 \mathrm{Ma}$ and the Zawyat Granite at $2187 \pm 33 \mathrm{Ma}$ (BGS, 2001a,b). All these plutonic bodies have been included in the Tazeroualt Suite. If the two groups of ages are confirmed in the future, an additional suite 
name should be given to the older group.

The Palaeoproterozoic basement inliers of Bas Drâa, Tagragra d'Akka, Ighrem and Tagragra de Tata also contain older low-grade (mainly greenschist facies) supracrustal metamorphic rocks, intruded by porphyritic calc-alkaline granites. These latter granites have given similar U-Pb SHRIMP and PIMMS zircon dates: Sidi Saïd Granite (Bas Drâa) - $1987 \pm 20$ Ma; Aït Makhlouf Granite (Ighrem inlier) - $2050 \pm 6 \mathrm{Ma}$ Targant and Oudad Granites (Tagragra de Tata inlier)$2046 \pm 7$ Ma and $2041 \pm 6$ Ma respectively (Aït Malek et al., 1998; Walsh et al., 2002). These granites are included in the Kerdous Suite.

The proposed lithostratigraphic nomenclature is limited to the Zenaga, Kerdous, Tagragra de Tata and Ighrem Complexes. In time, when other areas are studied, new names (e.g. Complexes, Suites etc) can be introduced, if necessary, to describe the rocks specific to that particular geographic area.

\section{NEOPROTEROZOIC SEQUENCES (800 to $550 \mathrm{Ma}$ )}

As is the general case in West Africa, no Mesoproterozoic rocks are known in the Anti-Atlas Orogen. In Thomas et al (2002), a lithostratigraphic scheme was proposed for the Sirwa Inlier, which can serve as the basis for the whole eastern Anti-Atlas Orogen. In general, the Neoproterozoic geology of this area is characterised by a number of rock sequences that are related to the evolution of the orogen in terms of its palaeogeography and tectonic setting. For the highest-order lithostratigraphic units, the term Anti-Atlas Supergroup is proposed to encompass all the Neoproterozoic volcanosedimentary rocks of the Anti-Atlas Orogen that were deposited before initial basin closure during the Pan-African Orogeny. Figure 3 shows a generalised stratigraphic log of the named units proposed.

\section{Middle Neoproterozoic rifting of the West African Craton, ocean-floor and island-arc formation, flysch sedimentation (Anti-Atlas Supergroup: $\sim 800$ ? Ma to $\sim 680 \mathrm{Ma}$ )}

The oldest rocks of the Anti-Atlas Supergroup comprise three discrete sequences related to the rifting and break-up of the northern margin of the West African Craton (represented by a passive margin sequence), the production of oceanic crust (preserved as metamorphosed ophiolitic remnants) and island-arc formation (thrust sheets of calc-alkaline meta-volcanic and plutonic rocks) in the period $\sim 800$ (?) to $740 \mathrm{Ma}$. The three broadly coeval products of this early extension-ocean formation-subduction phase were grouped by Thomas et al. (2002) into a 
"Bleïda Group", with various named components. However, as all but the passive margin sequence are allochthonous (i.e. the ophiolitic and island-arc remnants), we propose here that they should not form part of the same lithostratigraphic group. Thus, the passive margin shallow-water sequence preserved along the northern edge of the Zenaga Complex at the time of rifting of the West African Craton is termed the Taghdout Group (Fig. 3). In Thomas et al. (2002), this sequence was called the Taghdout Subgroup, part of the Bleïda Group. However, for the reasons stated above, the Bleïda Group thus defined is not acceptable in terms of lithostratigraphic principles, so the passive margin sequence is upgraded to group status. It is in turn subdivided into 3 formations of basalt, dolomite-shale and quartzite respectively, well exposed in the Type Area near Taghdout village, where a total of some 1500m of strata are preserved. It may be that the term "Bleïda" could be used in future to describe some of the rock sequences in the Bleïda area.

The Taghdout Group is associated with a swarm of doleritic dykes, sills and irregular sheet-like bodies that form a network of intrusions into the Zenaga Complex and sills within the lower part of the Taghdout Group. These rocks, geochemically akin to continental tholeiites are termed the Ifzwane Suite and are thought to be associated, along with the lower basalts of the Taghdout Group (Agouniy Formation), with the early rifting of the West African Craton.

In the Kerdous inlier, a comparable history is recorded. Mature sandstones equivalent to the 'Serie des Calcaires et Quartzites' are interpreted as having been deposited in a shoreline environment (Hassenforder, 1987). This thick succession of quartzites was termed the Jbel Lkst Group by BGS (2001c) and is the probable equivalent of the Taghdout Group. As at Zenaga, the rocks are intruded by an extensive suite of dolerites and gabbros termed the Toudma Suite (BGS, 2001c) that are the probable equivalents of the Ifzwane Suite. In the Bas Drâa, Tagragra d'Akka and the Tagragra de Tata inliers, comparable swarms of continental tholeiitic metadoleritic dykes are recognised, cutting the Palaeoproterozoic basement. Continental margin sedimentary rocks like the Taghdout and Jbel Lkst Groups are similarly recognised in these inliers.

Probably broadly coeval with the passive margin sequences of the Taghdout and Jbel Lkst Groups, which are only developed at the northern margin of the West African Craton, are the allochthonous ocean-floor rocks (ophiolites) which were produced as the floor of the ocean basin grew to the north of the passive margin. The largest, best-preserved and most complete ophiolitic fragment is developed at Bou Azzer in the SE Anti-Atlas. This area is thus designated as the Type Area of the Bou Azzer Group (Fig. 3), which includes all the ophiolitic fragments of the Anti-Atlas. The other two main outcrops are in the Sirwa region at Khazama and Nqob (Thomas et al., 2002). 
The Bou Azzer Group includes all rocks associated with the ocean floor, and comprises mantle harzburgites, layered gabbros, sheeted dykes, and submarine pillow basalts. Associated intrusive rocks such as the plagiogranites can also be given formal names. An example of the latter from near Bou Azzer has recently been dated at $\sim 760 \mathrm{Ma}$ (Admou et al., 2002). In due course, the various components of the Bou Azzer Group may be given formal lithostratigraphic names, such as the Nqob and Khazama Ophiolites in the Sirwa area. All the ophiolitic fragments are fault-bound and were tectonically transported to their present positions during the later stages of the Pan-African orogeny.

The third, allochthonous component of the early oceanic realm is composed of rocks that were produced in an island arc setting which formed by subduction of the oceanic crust north of the West African Craton margin (Fig. 3). The products of the island arc comprise medium-grade biotite-rich (andesitic) schists (Tachoukacht Schists) and associated deeper level layered tonalitic orthogneisses (Iriri Migmatite). The formal term Iriri Group is proposed for this sequence. It also includes the Ourika Complex, a lithologically similar schist-gneiss assemblage exposed to the north, in the High Atlas of the Ourika valley. The Iriri Group rocks are always in tectonic contact with other units. The protolith of the Iriri Migmatite has been dated at $743 \pm 14 \mathrm{Ma}$ (Thomas et al., 2002), confirming that it formed slightly after the ocean crust that is dated at $\sim 760$ Ma (Admou et al., 2002).

At about $750 \pm 100 \mathrm{Ma}$, therefore, an ocean basin and island $\operatorname{arc}(\mathrm{s})$ had developed north of the West African Craton. The Taghdout Group represents the proximal, shallow-water sediments, deposited at the rifted passive margin. More distally, the ocean basin was being filled with an enormous thickness of flysch-like turbiditic sediments and clastic rocks known as the Sarhro Group. In the Sirwa Inlier the thickness of the group is hard to ascertain, due to the scattered nature of the exposures, intense deformation and tectonic repetition. However, the original thickness is thought to exceed $8000 \mathrm{~m}$ (Thomas et al., 2002). In this area, the Sarhro Group is subdivided into 6 formations. The lowermost four formations are dominated by the products of deep-water flysch sedimentation, and volcanic and volcaniclastic rocks derived from the developing Iriri island arc, whilst the upper two formations are characterised by coarse, immature clastic sediments (conglomerates and arkoses). It is thought that the change from deep-water flysch to coarse clastic sedimentation was brought about by a change in plate movement vectors from early extension (ocean growth) to later contraction (closure and infilling of the basin), which culminated in the Pan-African orogeny, dated at $\sim 660$ Ma (Thomas et al., 2002).

In terms of the age of the Sarhro Group, the only direct constraints are that the rocks are older 
than $615 \mathrm{Ma}$, the age of the oldest granite (Ida Ou-Illoun batholith) that intrudes them (see below). Furthermore however, the Sarhro Group may be older than $660 \mathrm{Ma}$, the age of metamorphic zircons in the Iriri Group, associated with the early part of the Pan-African orogeny that deforms the group. In addition, it is noteworthy that one of the lowermost (flysch) formations contains a number of glacial diamictite horizons. Assuming that these diamictites are equivalent to one of the widespread Neoproterozoic diamictites found throughout Gondwana, the correlation must be with the older ( $\sim 700 \mathrm{Ma})$ unit, as the younger glacial event ( $\sim 600 \mathrm{Ma})$ took place after the deformation of the Sarhro Group. With regard to regional correlations, it appears that similar flysch-like sequences characterise the Jebel Sarhro massif and include the "Tidiline Series" of Leblanc (1973), the Sidi Flah, Kelaat Mgouna, Boumalne and Imiter Groups of Fekkak et al. (2001) and the Habab Group of BGS (2001e, f). It is proposed that the term Sarhro Group can be applied to all of these, with local subdivisions at sub-group and formation level within each inlier or massif. It is also possible with more work that the early flysch facies of the present Sarhro Group, associated with the opening oceanic basin could be lithostratigraphically separated from the later coarse clastic rocks associated with basin contraction and infill.

\section{Pan-African Orogeny in the Anti-Atlas (680 to $660 \mathrm{Ma}$ )}

The Pan African orogeny, which in the Anti-Atlas is represented by the closure of the ocean basin and subsequent accretion of the island $\operatorname{arc}(\mathrm{s})$ onto the northern, rifted edge of the West African Craton is not associated with any volcano-sedimentary sequences or igneous rocks. The dating of the collision is probably bracketed between $\sim 660 \mathrm{Ma}$ (metamorphic zircons - Thomas et al., 2002) and $\sim 680 \mathrm{Ma}$ (Leblanc and Lancelot, 1980). Thus, there is a hiatus in the geochronological record between 660 and $615 \mathrm{Ma}$. The early part of the collision history is represented by SW-directed thrusting and crustal stacking of, for example, the Taghdout Group onto the northern margin of the Zenaga Complex, and by folding, cleavage development and greenschist facies metamorphism in the Sarhro Group.

\section{Late orogenic history (Ouarzazate Supergroup: 615 to $550 \mathrm{Ma}$ )}

Magmatic rocks first break the hiatus in recorded sedimentary and magmatic events during the Pan-African Orogeny. In the Sirwa Inlier two vast $\left(>750 \mathrm{~km}^{2}\right)$ post-kinematic, composite high-K calc-alkaline (HKCA) batholiths of gabbro-diorite-granodiorite-granite were emplaced into, and contact metamorphosed, the deformed Sarhro Group rocks. In the Sirwa area these plutonic rocks have been grouped into the Assarag Suite (Fig. 3). The Ida Ou-Illoun batholith was dated at $615 \mathrm{Ma}$, while the rocks of the Askaoun batholith are somewhat younger at $\sim 580 \mathrm{Ma}$ (Thomas et 
al., 2002). In the Tiwit/lkniwn area of the Jebel Sarhro massif, several HKCA granites, granodiorites and igneous charnockites (Errami, 2001; Errami et al., 2002), known as the Bardouz Suite, intrude the Sarhro Group (BGS, 2001 e, f), whilst the equivalent rocks in the Kerdous Inlier are termed the Guellaba Suite. Such granitoids are thus typical of the Anti-Atlas Orogen and new suites will doubtless be identified in due course in different areas. The available reliable zircon dates on the HKCA granitoids range from 615 to $580 \mathrm{Ma}$ (Aït Malek et al., 1998; de Wall et al., 2001; Levresse et al., 2001, Thomas et al., 2002; Inglis et al., 2003), either reflecting episodic emplacement or part of an as yet incompletely defined continuum.

All the volcanosedimentary rocks that were deposited after the Anti-Atlas Supergroup have been grouped into the Ouarzazate Supergroup. During the time spanned by the intrusion of the Assarag Suite in the Sirwa area, a restricted sequence of bimodal volcanic (basalts and rhyolites) and coarse-clastic rocks was being deposited in fault-bounded grabens. These rocks form the first evidence of post-accretion deposition in the Anti-Atlas and represent precursors to the much more extensive molasse which follows. In the Sirwa region, some $2000 \mathrm{~m}$ of these rocks occur in two narrow, restricted fault-bound troughs where they are known as the Bou Salda Group (c.f. Bou Salda Formation in Thomas et al., 2002). Two associated rhyolites (Tadmant and Tamriwine Rhyolites) have given identical U-Pb SHRIMP ages of $605 \mathrm{Ma}$ (Thomas et al., 2002). Throughout the Anti-Atlas Orogen these early post-collision rocks occur in narrow fault-bound grabens and tend to have high tectonic dips of between $70^{\circ}$ and vertical. It is suggested that the grabens in which these rocks were deposited were strike-slip, pull-apart basins. The basins are interpreted to have developed in a sinistral transpressional regime initiated by continued post-collision convergence, along major strike-slip zones such as the Anti-Atlas Major Fault.

Similar proto-molasse sequences have been recorded in the Jebel Sarhro massif near Imiter, where huge-boulder conglomerates are developed. In this area, the sequence appears to be quite thick and the term Mgouna Group is proposed. In the Kerdous Inlier, the "Serie d'Anezi" (Choubert et al., 1973) occupies a similar lithostratigraphic position. This volcaniclastic succession was subdivided by BGS $(2001 a, b)$ into the basal Tafrawt Group (dominated by dacitic to rhyolitic ignimbrite) and the overlying Anzi Group (dominated by sandstone and conglomerate derived from the Tafrawt Group).

Unconformably overlying the plutonic rocks of the Assarag Suite and the "proto-molasse" of the Mgouna, Tafrawt, Anzi and Bou Salda Groups lies the upper part of the Ouarzazate Supergroup. These rocks comprise several groups, composed of thick and regionally extensive sequences of lavas, volcaniclastic rocks and coarse-grained immature clastic and epiclastic sedimentary rocks, 
which covers more than $60000 \mathrm{~km}^{2}$ encompassing the entire Anti-Atlas Orogen. The rocks are associated with alkaline sub-volcanic granite complexes, basic and acid dyke swarms, various rhyolitic plugs, domes and necks and gabbroic bodies. Due to the rapid and extreme facies variation (both sedimentary and volcanic) typical of such sequences, coupled with the recognition that some of the volcanic rocks were extruded from multiple interfingering volcanic centres, the lithostratigraphic subdivision of the upper Ouarzazate Supergroup over the entire orogen will undoubtedly prove to be incredibly time-consuming and complex. For example, in the Sirwa Inlier, Thomas et al. (2002) recognised that the volcanic rocks of the upper Ouarzazate Supergroup (their Ouarzazate Group) were the products of five broadly coeval interfingering volcanic centres, each with its own stratigraphy, and each subject to almost metre-scale facies variations. The different centres are here designated groups, subdivided into formations, if the centre was dominated by volcano-sedimentary rocks, or Formations for thinner, less extensive sequences, or Complexes for those centres dominated by sub-volcanic plutonic rocks in caldera complexes. Thus, in the Sirwa region alone the upper part of the Ouarzazate Supergroup is subdivided into three Groups (with a total of 13 Formations and 35 Members), one Formation and one Complex. It will clearly take a long time and require much effort for the entire Ouarzazate Supergroup to be formally lithostratigraphically subdivided in this fashion. In other areas, the Ouarzazate Supergroup was subdivided into separate subgroups on lithological grounds, not related to extrusion from different volcanic centres. The rhyolitic volcanism of the upper part of the Ouarzazate Supergroup spanned the period 575 to about $550 \mathrm{Ma}$ (Mifdal and Peucat, 1985; Thomas et al., 2002; BGS, 2001a-f; Walsh et al., 2002).

The upper part of the Ouarzazate Supergroup is associated with multiple high-level alkaline granite intrusions and sub-volcanic caldera complexes. Many of these are polyphase, with up to three phases recognised. In the Sirwa Inlier, these complexes are grouped within a single Toufghrane Suite (with 13 named granites) that spans the period 575 to $560 \mathrm{Ma}$ (Thomas et al., 2002).

In the Kerdous and Bas Drâa inlier, an equivalent suite of 10 syn- to post Ouarzazate Supergroup granites, spanning the period 545 to $579 \mathrm{Ma}$, have been termed the Guellaba Suite (BGS, 2001a, b, $g, h$ ). Similarly, in the Ikniwn/Tiwit area of Jbel Sarhro, two high-level granites are included in the Tanghourt Suite (BGS, 2001, e, f). Thus, utilization of this framework provides for the formal recognition of additional intrusive suites in other parts of the Anti-Atlas Orogen. The multitude of associated mafic and acid dykes and rhyolitic plugs associated with the Ouarzazate Supergroup have not been formally named at this stage. 
Disconformably following the Ouarzazate Supergroup in the Anti-Atlas Orogen are a thick sequence of carbonate-siliciclastic shale rocks with locally developed volcanic rocks that are termed the Tata and Taroudant Groups. The Precambrian-Cambrian boundary falls within the lowermost part of the sequence (Landing et al. 1998). These rocks developed within a gradually subsiding transtensional foreland basin (Tindouf Basin) that formed over, and to the south of, the Anti-Atlas orogen and sedimentation continued through the Palaeozoic and Mesozoic. The Tata and Taroudant Groups are thus not considered to be part of the Anti-Atlas Supergroup, but the lowermost unit of the next supergroup cycle (Tindouf Supergroup?), which falls outside the scope of this article.

\section{CONCLUSION}

The new lithostratigraphic system proposed for the Anti-Atlas Orogen is summarised in Table 1, where it is compared to the old chronostratigraphic nomenclature. It appears to encompass all the major units reported from throughout the orogen and is flexible enough so that, in future, newly recognised units (especially at the Formation, Member and Suite rank) can be added at the appropriate stratigraphic level. The scheme allows for both layered volcano-sedimentary and intrusive units to be incorporated and fits well with proposed evolutionary models of the belt:

1) Early continental break up of West African Craton (passive margin sedimentation: parautochthonous Taghdout and Jbel Lkst Groups) and continental tholeiitic magmatism (Ifzwane, Toudma Suites), possibly from $\sim 800 \mathrm{Ma}$;

2) Continued extension, ocean crust formation (allochthonous Bou Azzer Group ophiolitic fragments), subduction and island-arc formation (allochthonous Iriri Group tectonic slivers) in the interval 800 to $740 \mathrm{Ma}$;

3) Within the now-established ocean basin, flysch sedimentation (lower turbiditic Sarhro Group) took place, certainly before $615 \mathrm{Ma}$, probably before $660 \mathrm{Ma}$ and maybe before $700 \mathrm{Ma}$;

4) End of extension phase, plate movement vector reversal to convergence, ocean basin shrinks and fills (upper clastic Sarhro Group) culminating, probably at about $660 \mathrm{Ma}$, in;

5) Ocean basin closure, Pan-African accretion of Iriri island-arc onto northern margin of WAC, SW-directed thrusting, deformation of all pre-accretion rocks (grouped collectively into the Anti-Atlas Supergroup) including tectonic emplacement of remnant slivers of island-arc(s) (Iriri 
Group);

5) Continued and prolonged relative SW-NE movements give rise to major sinistral transpression zones such as the AAMF, causing lateral tectonic emplacement of allochthonous oceanic crustal ophiolitic slivers (Bou Azzer Group). Early high-K, calc-alkaline granitoid suites intruded at $\sim 615$ $\mathrm{Ma}$ (Assarag and Bardouz Suites). The entire volcanosedimentary pile associated with this tectonic phase is termed the Ouarzazate Supergroup. Into this active transpressive tectonic setting, the lower part of the Ouarzazate Supergroup (Bou Salda, Mgouna, Tafrawt and Anzi Groups) were deposited in narrow strike-slip, pull-apart grabens at $\sim 605 \mathrm{Ma}$. Emplacement of HKCA batholiths continued to $580 \mathrm{Ma}$ (episodic or continuous?);

6) True continental molasse volcano-sedimentary rocks of the upper part of the Ouarzazate Supergroup were deposited in settings associated initially with still-active major strike-slip fault zones from $\sim 580 \mathrm{Ma}$. Followed by more extensive overlapping deposition and magmatism from numerous interfingering volcanic centres (many with exposed sub-volcanic caldera complexes and associated alkaline granites: Toufghrane, Guellaba, Takatart and Tanghourt Suites), due to orogenic collapse and regional extension from 575 to $545 \mathrm{Ma}$;

7) Posterior to the Anti-Atlas Orogen, subsidence of extended crust (transtension), marine incursion and major foreland basin formation (Tindouf Basin) from latest Neoproterozoic times into the Lower Palaeozoic (Tata and Taroudant Groups).

\section{ACKNOWLEDGMENTS}

The authors are indebted to Kevin Hefferan and Scott Sampson for their thorough, thoughtful reviews. Bob Thomas and Sue Loughlin publishes with permission of the Executive Director, British Geological Survey, (NERC).

\section{REFERENCES}

Admou, H., Samson, S., Essaifi, A., Wafik, A., 2002. A new datation at $760 \mathrm{Ma}$ of the plagiogranites associated to the Neoproterozoic Bou-Azzer and Siroua ophiolite (Anti-Atlas, Morocco). Abstract 19th Coll. African Geology, El Jadida, Morocco, 4-5.

Aït Malek, H., Gasquet, D., Bertrand, J.M., Leterrier, J., 1998. GéchronologieU-Pb sur zircon de granitoïdes éburnéens et panafricains dans les boutonnières protérozoïques d'Igherm, du 
Kerdous et du Bas Drâa (Anti-Atlas occidental, Maroc). Comptes Rendues Académies Sciences, Paris, 327, 819-826.

BGS, 2001a. Carte géologique du Had-n-Tahala au 1/50 000. Notes et Mémoires, 403, Editions du Service Géologiques du Maroc, Rabat.

BGS, 2001b. Carte géologique d"Anzi au 1/50 000. Notes et Mémoires, 402, Editions du Service Géologiques du Maroc, Rabat.

BGS, 2001c. Carte géologique de Tanalt au 1/50 000. Notes et Mémoires, 401, Editions du Service Géologiques du Maroc, Rabat.

BGS, 2001d. Carte géologique de Barrage Youssef Ben Tachfine au 1/50 000. Notes et Mémoires, 400, Editions du Service Géologiques du Maroc, Rabat.

BGS, 2001e. Carte géologique de Tiwit au 1/50 000. Notes et Mémoires, 404, Editions du Service Géologiques du Maroc, Rabat.

BGS, 2001f. Carte géologique d'Ikniwn au 1/50 000. Notes et Mémoires, 405, Editions du Service Géologiques du Maroc, Rabat.

BGS, 2001g. Carte géologique de Tilamsoun au 1/50 000. Notes et Mémoires, 406, Editions du Service Géologiques du Maroc, Rabat.

BGS, 2001h. Carte géologique d'Al Youn Dar"a au 1/50 000. Notes et Mémoires, 407, Editions du Service Géologiques du Maroc, Rabat.

Choubert, G., 1963. Histoire Géologique du Précambrien de l'Anti-Atlas. Notes \& Mem. Serv. geol. Maroc., 162, 7-352.

Choubert, G., Boudda, A., Faure Muret, A., 1973. essai de chronologie du Précambrien supérieur du sud marocain. CRS Société. Géologique France 15, 123-124.

De Wall, H., Kober, B., Greiling, R.O., Errami, E., Ennih, N., 2001. Age and structural setting of the grantoid emplacement in the area of Imiter (Eastern Saghro). Abstract, 2nd Coll. 3M. Marrakech, p.19. 
Ennih, N., Liégeois, J.P., 2001. The Moroccan Anti-Atlas: the West African craton passive margin with limited Pan-African activity. Implications for the northern limit of the craton. Precambrian Research, 112, 291-304.

Errami, E. 2001, Les granitoïdes panafricains post-collisionnels du Saghro oriental (Anti-Atlas, Maroc). Etude pétrologique et structurologique par l'Anisotropie de Susceptibilité Magnétique (ASM). Thèse, Université El Jadida, 265p.

Errami, E., Liégeois, JP., Laduron, D., Ennih, N., 2002. The Pan-African post collisional high-k granitoids (Eastern Saghro, Anti-Atlas, Morocco); witness for a metacrtaonic margin?. In Abstract $19^{\text {th }}$ Coll. African Geology, El Jadida, Morocco, p.85.

Fekkak, A., Boualoul, M., Badra, L., Amenzou, M., Saquaque, A., El Amrani, I.Z., 2000. Origine du du matériel détritique et contexte géotectonique du bassin précambrien de Kelaat Mgouna (Anti-Atlas, Maroc). Journal African Earth Sciences, 30/2, 295-311.

Fekkak, A., Pouclet, A., Ouguir, H., Ouazzani, H., Badra, L., Gasquet, D., 2001. Géochimie et signification géotectonique des volcanites du Cryogénien inférieur du Saghro (Anti-Atlas oriental, Maroc). Geodinamica Acta, 14, 373-385.

Hassenforder, B., 1987. La tectonique Panafricaine et Varisque de l'Anti-Atlas dans le massif du Kerdous (Maroc). Ph.D thesis, Univ. Louis Pasteur, Strasbourg, 220pp.

Hefferan, K.P., Karson, J.A., Saquaque, A., 1992. Proterozoic collisional basins in a Pan-African suture zone, Anti-Atlas mountains, Morocco. Precambrian Research, 54, 295-319.

Inglis, J.D., MacLean, J.S., Samson, S.D., D'Lemos, R.S., Admou, H. and Hefferan, K., 2003. A precise U-Pb zircon age for the Bleida granodiorite, Anti-Atlas, Morocco : consequences for the timing of deformation and terrane assembly in the eastern Anti-Atlas. Journal African Earth Sciences (this issue).

Landing, E., Bowring, S.A., Davidek, K.L., Westrop, S.R., Geyer, G., Heldmaier, W., 1998. Duration of the Early Cambrian: U-Pb ages of volcanic ashes from Avalon and Gondwana. Canadian Journal Earth Sciences, 35, 329-338. 
Leblanc, M. 1973. La tectonique du Précambrien II dans la région de Bou-Azzer (Anti-Atlas central). Notes et Mémoires Service Géologique Maroc, 33, 249, 59-82.

Leblanc M. \& Lancelot J.R., 1980. Interprétation géodynamique du domaine panafricain (Précambrien terminal) de l'Anti-Atlas (Maroc) à partir de données géologiques et géochronologiques, Canadian Journal Earth Sciences, 17, p. 142-155.

Levresse G., Azizi M.S., Cheilletz A., Gasquet D., Zyadi R., Ennaciri D., Archibald D., Ouguir, $\mathrm{H}$., 2001. Le gisement Ag-Hg d'Imiter (Anti-Atlas, Maroc): Nouvelles données U-Pb, ${ }^{40} \mathrm{Ar} /{ }^{39} \mathrm{Ar}, *{ }^{34} \mathrm{~S}$ et microstructurales appuyant le modèle génétique hydrothermal-épithermal. In Abstract $2^{\text {nd }}$ Coll. 3M. Marrakech. p 97.

Mifdal, A., Peucat, J. 1985., Datation U-Pb et Rb-Sr du volcanisme acide de l'Anti-Atlas marocain et du socle sous jacent de la région de Ouarzazate. Apport au probleme de la limite Précambrien - Cambrien. Sciences Géologiques Bulletin, 38, 185-200.

Saquaque, A., Beharref, M., Abia, H., Nrini, Z., Reuber, I., Karson, J.A., 1992. Evidence for a Pan-African volcanic arc and wrench fault tectonics in the Jbel Saghro, Anti-Atlas, Morocco. Geologische. Rundschau., 81, 1-13.

Thomas, R.J., Chevallier, L.C., Gresse, P.G., Harmer, R.E, Eglington, B.M., Armstrong, R.A., de Beer, C.H. Martini, J.E.J., de Kock, G.S., Macey, P., Ingram, B., 2002. Precambrian evolution of the Sirwa Window, Anti-Atlas Orogen, Morocco. Precambrian Research, 118, 1-57.

Walsh, G.J., Aleinikoff, J.N., Benziane, F., Yazidi, A., Armstrong, T.R. 2002. U-Pb zircon geochronology of the Palaeoproterozoic Tagragra de Tata inlier and its Neoproterzoic cover, western Anti-Atlas, Morocco. Precambrian Research 117, 11-20.

\section{Figure Captions}

Fig 1. General map of Anti-Atlas Orogen, showing distribution of the Anti-Atlas and Ouarzazate Supergroups.

Fig. 2. Map of distribution of Palaeoproterozoic basement in the Anti-Atlas region. 
Fig. 3. Generalised lithostratigraphic column for the Anti-Atlas Orogen.

\section{Table Caption}

Table 1. Comparative lithostratigraphic nomenclature of the Anti-Atlas Orogen, with the scheme proposed by this study. 


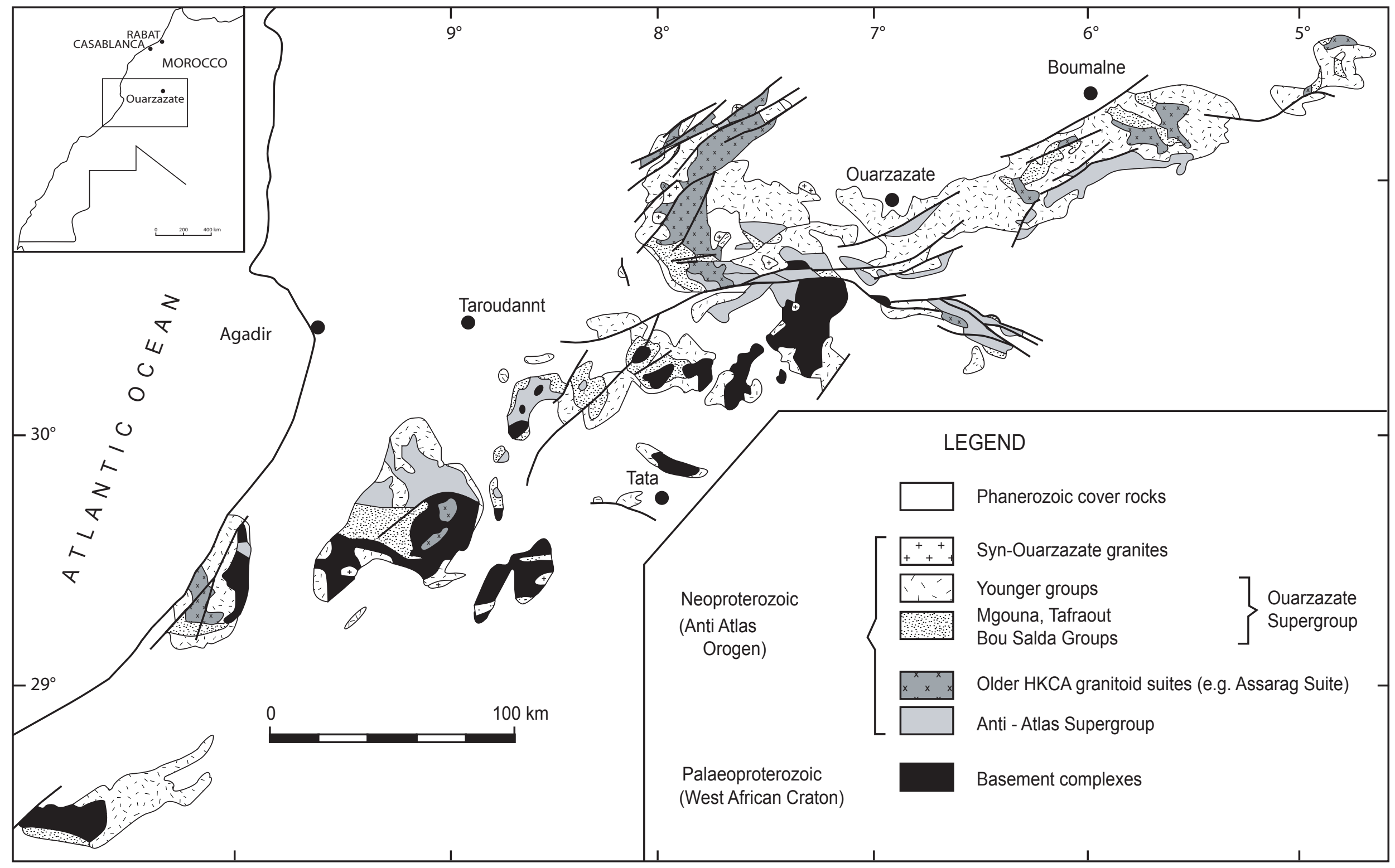




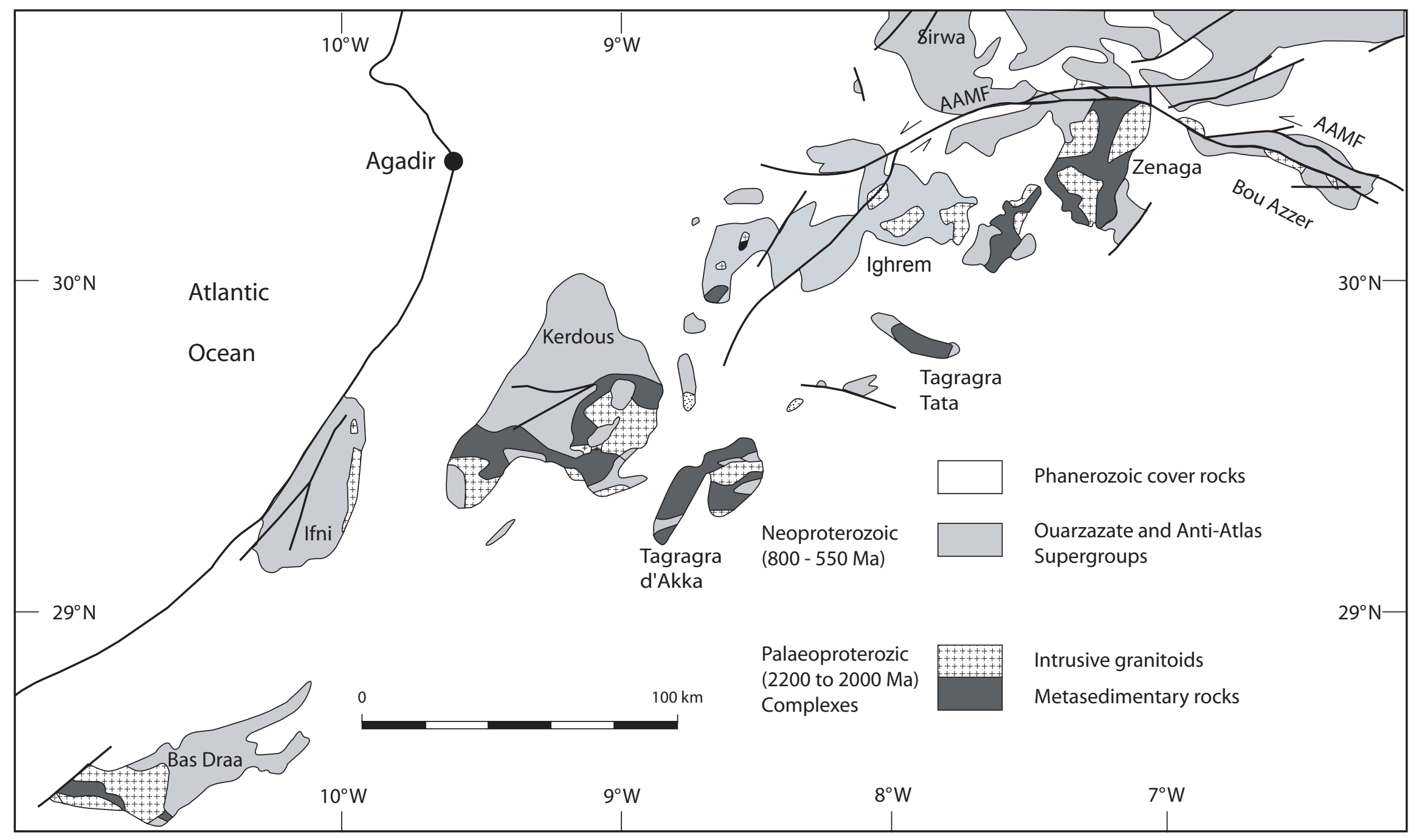




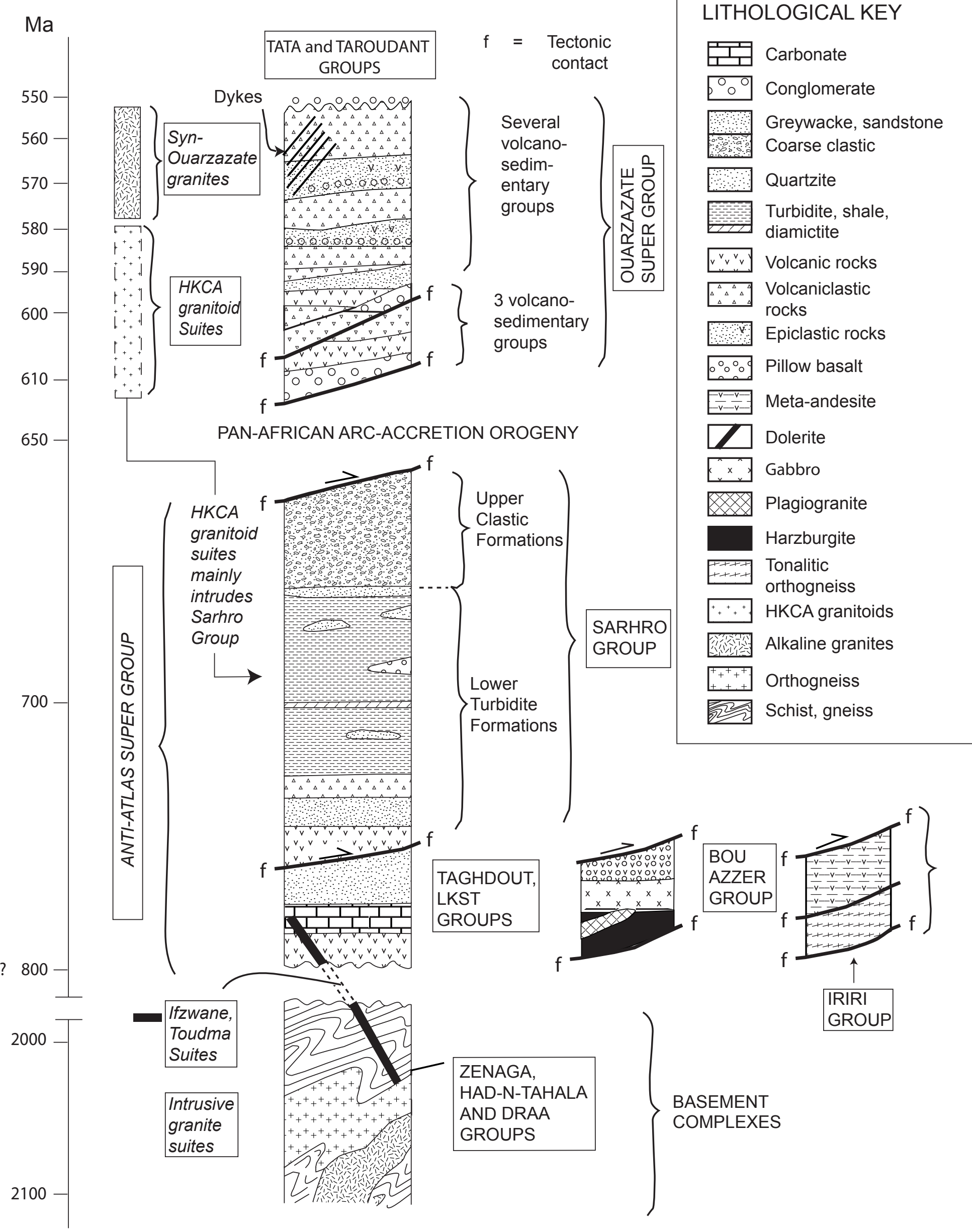




\begin{tabular}{|c|c|c|c|c|c|c|c|}
\hline \multicolumn{2}{|c|}{$\begin{array}{l}\text { Volcanosedimentary } \\
\text { rocks }\end{array}$} & $\begin{array}{l}\text { Intrusive igneous } \\
\text { rocks (descriptive) }\end{array}$ & $\begin{array}{l}\text { Kerdous and Bas Dra } \\
\text { Inliers }\end{array}$ & $\begin{array}{l}\text { Sirwa I Bou Azzer } \\
\text { Inlier }\end{array}$ & Sarhro Inlier & $\begin{array}{l}\text { Old } \\
\text { symbols }\end{array}$ & Age and setting \\
\hline & & Basalt/gabbro & Takatart Suite & & & & Transtension? \\
\hline \multirow{2}{*}{\multicolumn{2}{|c|}{$\begin{array}{l}\text { Ouarzazate } \\
\text { Supergroup }\end{array}$}} & & $\begin{array}{l}\text { Ait Baha, Anzi, Tanalt, } \\
\text { Fiyzirt, Oufoud, Jbel Guir } \\
\text { and Taarotihate Groups }\end{array}$ & $\begin{array}{l}\text { Tiouin, Bouljama, } \\
\text { Tafrant Groups, } \\
\text { Achkoukchi Complex, } \\
\text { Aghbar Formation }\end{array}$ & $\begin{array}{l}\text { Imlas, Mançour } \\
\text { Subgroups }\end{array}$ & \multirow[t]{2}{*}{ PIII } & \multirow[t]{2}{*}{$\begin{array}{l}580 \text { to } 545 \mathrm{Ma}: \\
\text { extensional } \\
\text { molasse with } \\
\text { caldera } \\
\text { complexes }\end{array}$} \\
\hline & & $\begin{array}{l}\text { Syn-Ouarzazate } \\
\text { granites }\end{array}$ & \multirow{2}{*}{ Guellaba Suite } & Toufghrane Suite & Tanghourt Suite & & \\
\hline & & HKCA granitoids & & Assarag Suite & Bardouz Suite & PIII & $\begin{array}{l}615 \text { to } 580 \mathrm{Ma}: \\
\text { Post-tectonic } \\
\text { granitoids }\end{array}$ \\
\hline \multicolumn{2}{|c|}{$\begin{array}{l}\text { Ouarzazate } \\
\text { Supergroup "precursor } \\
\text { rocks" }\end{array}$} & & Tafrawt, Ansi Groups & Bou Salda Group & Mgouna Group & $\mathrm{PII}^{3}$ or PIII & $\begin{array}{l}605 \mathrm{Ma}: \\
\text { Strike-slip } \\
\text { pull-apart basins }\end{array}$ \\
\hline \multicolumn{7}{|c|}{ PAN - AFRICAN ACCRETION OROGENY } & $\sim 660 \mathrm{Ma}$ \\
\hline \multirow{3}{*}{\multicolumn{2}{|c|}{ Anti-Atlas Supergroup }} & & \multicolumn{3}{|c|}{ Sarhro Group } & $\begin{array}{l}\mathrm{PII}^{2} \text { or } \\
\mathrm{PII}^{3}\end{array}$ & $\begin{array}{l}\text {-700 to } 660 \mathrm{Ma}: \\
\text { Flysch basin }\end{array}$ \\
\hline & & Dolerite, gabbro & Toudma Suite & Ifzwane Suite & Un-named & $\mathrm{PII}^{2}$ & $\begin{array}{l}\text {-780 Ma: } \\
\text { extension }\end{array}$ \\
\hline & & $\begin{array}{l}\text { Plagiogranite in Bou } \\
\text { Azzer Group }\end{array}$ & Jebel Lkst Group & $\begin{array}{l}\text { Taghdout, Bou Azzer, } \\
\text { Iriri Groups }\end{array}$ & $\begin{array}{l}\text { Taghdout, Bou } \\
\text { Azzer Groups }\end{array}$ & $\mathrm{PII}^{2}$ & $\begin{array}{l}\text { 800 to } 700 \text { Ma: } \\
\text { Passive margin, } \\
\text { ocean floor, arc }\end{array}$ \\
\hline \multicolumn{8}{|c|}{ VERY LONG TIME INTERVAL } \\
\hline \multirow[t]{3}{*}{$\begin{array}{l}\text { Basement } \\
\text { complexes }\end{array}$} & & Granitoids & $\begin{array}{l}\text { Kerdous, Draa } \\
\text { Complexes: }\end{array}$ & Zenaga Complex: & \multirow[t]{3}{*}{ Not present } & \multirow[t]{3}{*}{ P1 } & \multirow[t]{3}{*}{$\begin{array}{l}\text { 2200 to } 2035 \\
\text { Ma: Eburnian } \\
\text { basement }\end{array}$} \\
\hline & & & $\begin{array}{l}\text { Tazeroualt and } \\
\text { Mechebbouk Suites }\end{array}$ & Tazenacht Suite & & & \\
\hline & Schists & & $\begin{array}{l}\text { Had-n-Tahala and Draa } \\
\text { Groups }\end{array}$ & Zenaga Group & & & \\
\hline
\end{tabular}

